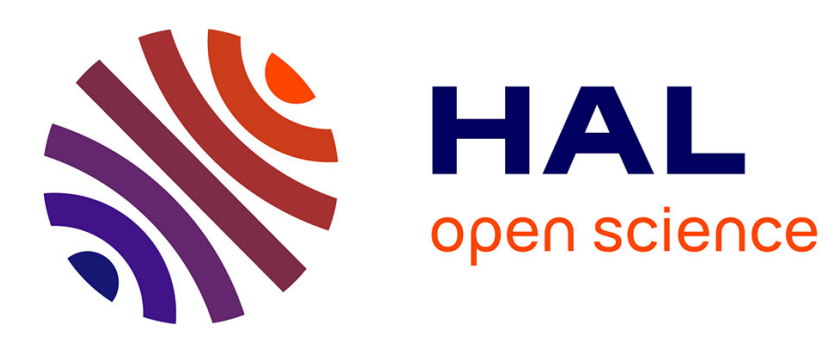

\title{
Second Generation, Third Generation, and State Political Postmemory: The Holocaust and Its Literary Effects in Contemporary France
}

Frédérique Leichter-Flack

\section{- To cite this version:}

Frédérique Leichter-Flack. Second Generation, Third Generation, and State Political Postmemory: The Holocaust and Its Literary Effects in Contemporary France. Journal of Literature and Trauma Studies, 2016, 4 (1), pp.67-77. 10.1353/jlt.2016.0000 . hal-01769170v2

HAL Id: hal-01769170

https://hal.parisnanterre.fr/hal-01769170v2

Submitted on 10 Feb 2020

HAL is a multi-disciplinary open access archive for the deposit and dissemination of scientific research documents, whether they are published or not. The documents may come from teaching and research institutions in France or abroad, or from public or private research centers.
L'archive ouverte pluridisciplinaire HAL, est destinée au dépôt et à la diffusion de documents scientifiques de niveau recherche, publiés ou non, émanant des établissements d'enseignement et de recherche français ou étrangers, des laboratoires publics ou privés. 


\title{
Second Generation, Third Generation, and State Political Postmemory
}

\author{
The Holocaust and Its Literary Effects in \\ Contemporary France \\ FRÉDÉRIQUE LEICHTER-FLACK
}

This article aims to offer a reflection on the interaction between literature, the postmemory of the Holocaust as Marianne Hirsch describes it and the political sphere in contemporary France. ${ }^{1}$ In the fields of literature and film, many works have dealt with the Holocaust. France is perhaps the European country where the idea of a "duty of memory" regarding the genocide of the Jews and the country's own past under Nazi occupation has been most discussed. One may observe the same interest in direct testimonies by survivors of the genocide in France as in the United States. However, the last fifteen years have been characterized by two simultaneous phenomena: first, the coming of age of a "third generation" with its own specific questions, which is willing to take over from the second generation and which has been extensively studied by psychoanalysts, and second, a complete renewal of the political context: the Holocaust, and the active role the French state played in it, are now considered inescapable parts of national political memory. Through a discussion of a number of particularly striking French-language contemporary works, this article will explore the effect on literary writing of the interaction between a generational phenomenon and highly interventionist memory politics. I ask, first, what is happening to literature regarding the family memory of the 
Holocaust in this third-generation context? Second, beyond family and community legacy, are we moving toward a national postmemory highlighting passivity in front of the genocide?

To begin with, two books published in the 2010 s have presented themselves as grounded in this third-generation experience. Both are characterized by a highly structured critical metadiscourse on their own approach. In Histoire des grands-parents que je n'ai jamais eus (A history of the grandparents I never had), the historian Ivan Jablonka uses the methods specific to his disciplinary field-through which he usually explores subjects unconnected to his Jewishness - to investigate the story of his grandparents who died in Auschwitz. ${ }^{2}$ The author follows their trail through archives to piece their lives back together, from their youth in Poland, to their involvement in the Communist Party, their activism in France, their going underground, and finally their arrest and death. This is a work of what is now called in academic circles microhistory, but what makes it strikingly different from the usual pattern of such works among French historians is its undisguised claim to subjectivity. The author, who is of Jewish descent and was born in France in the 1970s, writes in the first person, questions his own quest and motivations, and asserts his identity as a writer as well as a historian. But he explicitly forbids himself from resorting to literature to fictionalize episodes insufficiently documented by history. Cultivating attention to the singularity of individual lives in the midst of anonymous crowds, the book may remind us of The Lost by Daniel Mendelsohn, which became popular among French readers when it was released in 2007. However, Mendelsohn's book is not Jablonka's only model: microhistories, biographies, literary investigations, first-person narratives, family stories-his book is based on a form of reasoned hybridity, extremely aware of its own status, sources, commitments and limits.

Another third-generation work is La vie après (Life after), by Virginie Linhart, an essay written in parallel to a documentary film that she directed for the French public television network. ${ }^{3}$ Linhart, a filmmaker and writer, is the granddaughter of Jews who escaped the Holocaust by hiding in Switzerland during the war. Linhart explains that she embarked her project to answer her own questions about identity and to shed light on the darker episodes of her family's history. Her approach is original, since she does not interrogate, at least not at length, what her grandparents' 
friends went through during the war in the death camps or in their secret hiding places. Instead, she focuses on the aftermath of that traumatic experience: how they pieced themselves back together, how they managed to return to ordinary life after surviving the death camps. Linhart observes that the period immediately after persecution is the blind spot in the otherwise abundant historiography devoted to the Holocaust in France. Despite the return to France after the war of nearly twenty-five hundred Jews out of the seventy-five thousand deported to the Nazi death camps, this period remains little discussed in the many testimonies by survivors that have been published. To illuminate that history, Linhart obtained testimonies from around twenty survivors centered on the postwar period, the days when they sought to return to normalcy and sew together their lives, ripped by loss and trauma. In her book Linhart explains the difficulty of her endeavors: " $[\mathrm{D}]$ escribing life after means accepting to disclose intimate, singular moments, the ups and downs of life.... Telling about life after means abandoning the ' $w e$ ' of the collective tragic destiny and saying 'I' as an individual. ... The collective 'we' protects, the 'I' leaves you exposed." Indeed, the hardship that returning to ordinary life after the camps entailed for the generation of survivors was underestimated. This was the moment when a traumatized individual's psyche had to decide how to deal with the trauma, how to manage it. Nothing was provided, of course, for the camp survivors, most of whom had no resources and no families-no official period of mourning, no help from the community, no public assistance, no emotional and psychological support, no social recognition. As they improvised a new family life, "life after" was also the foundation of what psychologists have called the second generation. Linhart asserts that this also may be true of the third generation, "because in the conditions of this return lie the foundation of my present obsession, the silence which enveloped their lives and marked our childhoodthe childhood of the descendants of that tragedy."5 In Linhart's work the whole process of transfer of memory involves the grandparents and grandchildren. The second generation is completely left out, outside the frame.

The second generation is, however, the central theme of another work that was also published in 2012 in France: a masterly graphic novel by the Belgian-born Israeli caricaturist Michel Kichka. Deuxième génération (Second generation) deals with the way in which the author's father, who was a 
teenager when he left Auschwitz as a survivor, managed his family life and raised his children in the shadow of the Holocaust. ${ }^{6}$ The book is shows clear inspiration from Maus, by Art Spiegelman, and at the same time it is distinct in a number of ways. First, there is an explicit shift in focus: Deuxième génération does not aim at telling the story of the father's time in Auschwitz but instead tells the story of the son, the author, from his childhood in Belgium up to his present-day adult life as a husband and father in Israel. It is a sort of biographical graphic novel about the author that offers an example of the experiences of the "second generation," which is well known to psychologists. And because the picture of this second generation is so well known, it is possible to approach it with humor, complicity and tenderness. This is what makes this book a masterpiece and an indication of changing times.

Indeed, one finds in Kichka's graphic novel, as in Spiegelman's Maus, all the characteristic elements of the experience of the second generation: a childhood marked by the telling silence of a survivor father who measures everything by the yardstick of Auschwitz; the discovery of the genocide by the son, through pictures seen when he was seven or eight in the history books about the Holocaust that his father collected, and the nightmares he had as a result; an adolescence that offered no possibility of rebelling because of the weight of the father's suffering ("I couldn't graduate from school because of the Nazis, so please, make sure you are always the best in your class" ${ }^{\prime}$ ); the repressed memory of the second generation coming back, when the author's brother committed suicide as an adult; and the difficulties of the father-son relationship, characterized by the discrepancy between the public persona of the father, a witness to and hero of the Holocaust, and his private personality, self-centered and grumpy. However, since all these characteristic features of the second-generation syndrome have already been documented, and since Kichka writes from his position as a father who has led his own life and nursed his own wounds, he can offer, as a caricaturist, a sensitive and humorous picture. For instance, the father's obsession is illustrated as early as the first page of the graphic novel, in a scene where the family has dinner and the father exclaims, "Yum, this soup reminds me of Auschwitz! You know why?" "No, daddy," the children answer. "Because we never had any in that place!" some idea of the tone. Time has passed since Maus was published: enough 
time for the adult caricaturist to be able to sketch, with humor and quirky tenderness, his own nightmares as a child haunted by the Holocaust. For instance, one panel shows Kichka's own father, dressed as a sheriff and holding in a cell a baddie named "Adolf the Ugly," for whose capture a sixmillion-dollar bounty was offered, as a poster on the wall reveals. ${ }^{9}$

Through this intertextuality and complicity with readers, Deuxième génération has what informed readers will clearly perceive as a tongue-incheek relationship with Maus. It very much takes the tone of an era saturated with psychoanalysis casting an amused and sympathetic look on an older period when there were no psychoanalysts and nobody thought of warning fathers against repeating to their young sons, "You are my revenge on Hitler!” Indeed, in this sense Deuxième génération is a post-second generation work, a graphic novel in which psychology is obviously there, but only as an old, familiar figure who no longer has anything to teach and from whom one cannot expect anything new, but with whom one can be comfortable and have fun, because one has to deal with trauma, not necessarily try and repair it. This is evidenced in the wild scene at the end of the graphic novel in which three generations - the grandfather, the son, and the grandsons - sit around a table laughing and sharing dreadful jokes and puns about the Holocaust, with the readers' benevolent complicity.

Alongside the development of a postmemory by Jewish descendants of Holocaust survivors, France has gone through a major period of conflict about memory over the last fifteen years. A number of public initiatives have thoroughly altered the status and uses of the memory of the genocide of the Jews. These state-sponsored memory policies have, first, contributed to the inclusion of Jewish memories into the national memory. A central emotional interest in the Holocaust can thus be identified in a large number of works of fiction published by French non-Jewish authors who have no direct link to the genocide of the Jews, neither family nor community connections. But the inclusion of this trauma into the national memory has been accompanied by a shift of focus, from the horror felt in the face of what happened to the victims to anguished debates about responsibility and an obsessive moral questioning.

In 1995 Jacques Chirac, the president of the French Republic, established the sixteenth of July as a day of remembrance, marking the day in 1942 when French police conducted mass arrests of more than thirteen 
thousand Jews in Paris and its suburbs and held them in a popular covered cycling arena, an event remembered in Parisian vernacular as the "rafle du Vel d'Hiv." Chirac announced the date as "a national day of remembrance for the victims of the racist and anti-Semitic crimes of the French state and for France's Righteous." ${ }^{10}$ In a groundbreaking speech, he acknowledged what no French official had ever acknowledged before: the responsibility of the French state in the extermination of the French Jews. While the French Republic by this time accepted the legacy of Vichy France and courageously offered official recognition of past crimes, the theme of France's Righteous among the Nations was progressively taken out of its original Jewish and Israeli context-it is an honorary title conferred on people by Jerusalem's Yad Vashem — and adopted by the French authorities to use as evidence of French memory policies. Those policies culminated in 2007, when France's nearly three thousands Righteous among the Nations were honored with a symbolic collective inscription at the Pantheon, the republican mausoleum dedicated to the memory of France's great men and famous for containing the ashes of heroes of France's republican history, such as Voltaire, Rousseau, Victor Hugo, Zola, and Jean Moulin. As early as 2000, the sixteenth of July had become the national day of remembrance for the victims of racist and anti-Semitic crimes, as well as a day of tribute to France's Righteous.

The film La rafle (The round-up, 2010), directed by Roselyne Bosch, offers a synthesis of this national postmemory and its objective of reconciliation. This film, which mixes fiction with historical reenactment, brings together all the elements of the French memory pick-and-mix regarding the genocide of the Jews: the shame, indignity, and guilt associated with the key role played by the French police in the Vel d'Hiv mass arrests of July 1942, but also the heroic intervention of some of France's Righteous, who show the way, providing the happy ending as the child hero of the film escapes. Above all, the film offers the cinematic prop that the national memory needed to stabilize this contrasted and soothing picture, as the film re-creates the setting of the Vel d'Hiv in 1942, of which no photographic archive exists. The film therefore presents itself as an ideal tool for history teachers.

The double-bind that characterizes the French national memory of the Nazi occupation is, politically, productive. It provides a form of clo- 
sure. However, on a more individual level, it leaves ordinary French citizens with uncertainties about their worth, as compared with the exemplary Righteous and the abhorrent collaborationists. The most threatening figure is, then, the middle ground, the mass of people who neither resisted nor collaborated but satisfied themselves with carrying on with their lives amid the hardship of the occupation and did not bother to look at whatever worse things were happening to people around them. In thirdgeneration France, different family memories still coexist, but they now have to contend with national memory. This is the case for the third generation of descendants of the Righteous, who are called upon to act as spokespeople for their exemplary grandparents, who often achieved recognition recently. This is also the case for the third generation of descendants of collaborationists, as the polemical book Des gens très bien (Very nice people) illustrates. ${ }^{11}$ This hatchet-job, which was criticized for being excessive and therefore indulgent, was published by the bestselling author Alexandre Jardin in 2010. In the book Jardin explores the figure of his own grandfather, who was the chief of staff of the collaborationist prime minister Pierre Laval when the Vel d'Hiv mass arrests took place.

A change in the context of memory politics affects everyone's relationship to his or her own family history. Even when one is the descendant neither of a collaborationist nor of Jews sent to the camps, such a change means that one cannot be really comfortable with one's family history, which must be assessed anew from a moral perspective. The interaction between the memory of the Holocaust and literary creation is grounded in that moral questioning about involvement: Who did something? Why? Could you know how you would have chosen between good and evil under duress? Who would have collaborated and who would have behaved righteously? The title of a recent essay by Pierre Bayard, Aurais-je été resistant ou bourreau? (Would I have been a resistance fighter or an executioner?), is clearly attuned to that public mood, to how the collective memory is grounded in a moral questioning. ${ }^{12}$

This question corresponds, as Primo Levi wrote in "The Gray Zone," to a temptation on the part of those who arrive late on the scene to simplify things and pass judgment, thereby separating the righteous from the wicked as Christ will on the day of the last judgment, whereas reality is infinitely more complex. ${ }^{13}$ Such a question is, therefore, probably mislead- 
ing, as Bayard also acknowledges: the title of his book is a way of playing on people's doubts about themselves. Would I have been a hero? Would I have become a persecutor? For most people, the answer is, of course, neither. The immense majority of people chose neither good nor evil. They just accepted things as they were, waiting to see what would happen. They were not able to identify in their daily lives, which had been dramatically altered by the war and the occupation, the situations that demanded that they react, intervene, and make choices. What if today's trauma was based on that question? The results of experiments in social psychology conducted by behaviorist psychologists from Milgram onward have been broadly discussed and have popularized the notion that passivity is the ultimate weakness, evil being the result of nonintervention. Now, what is to be made of that weakness? It appears most pressing to control it, to protect it against itself, to set up social and political devices to prevent the natural trend toward criminal passivity from having disastrous consequences.

This is not the direction in which readers are taken in a recent book by Yannick Haenel, entitled in French with the name of its hero, Jan Karski, and translated into English as The Messenger. ${ }^{14}$ The uproar that this book created takes us back to the core of the present interaction between postmemory and literary creation, namely, when a moral understanding of the collective trauma of memory turns into ideology.

The Messenger is a fictional "I remember" story, a vicarious "I remember" story that was one of the great successes of the 2009 Parisian "rentrée litterraire" following a writing retreat the author attended at the statesponsored Villa Medici in Rome. As such, it is profoundly disturbing, since the author, a Parisian French writer in his forties, puts words in the mouth of the hero of the Polish resistance, Jan Karski, the man who entered the Warsaw ghetto at his peril in order to report to the world, as an eyewitness, on what was happening there and then secretly crossed all the borders of occupied Europe to go and tell Roosevelt, in Washington, about the extermination of Jews that was taking place in Europe. We know that Karski reported in vain, that the Allies did not make stopping the genocide of the Jews a priority objective in the war against Nazism. Karski, who died in 2000, told his story in a book published in 1944, Story of a Secret State. Haenel uses the historical figure of Karski and has him support a thesis that, given the success of the book in the autumn of 2009, 
seems to have been accepted without discussion in contemporary France: that the Allies knew what was happening to the Jews and let it happen, that they were complicit in the genocide of the Jews and as guilty as the Nazis who organized it.

Haenel uses his own filmographic memory of Jan Karski, namely the impression left on him by Karski's testimony in the 1985 film Shoah, directed by Claude Lanzmann, which Haenel describes minutely in the first half of the book. He then decides - making rash use of the freedom granted by fictional writing - to attribute to Karski a trauma that Karski himself never evoked, in order to imagine-and that is the third part of the book-a shadow, fictional testimony in which the elderly Polish hero, toward the end of his life, would express all his bitterness toward the moral complicity of the Allies in the genocide of the Jews. However, this fictional memory, "borrowed" from the historical figure and "made his own" by a fortysomething writer in France in 2009, is an ideological form of memory. The thesis of the moral equivalence between the passive knowledge of the Allies and the active crime of the Nazis raises all sorts of problems. Haenel reopens a historical discussion that, in spite of its complexity, professional historians have somehow put an end to. He reopens it to assess history and international relations in purely moral terms, as one would make an individual choice between good and evil. But this implies a simplistic vision of what a just war consists of and delegitimizes the motives of the American intervention in Europe. Without openly acknowledging it politically, it encourages a form of generalized moral relativism, between the moral failures of the passive witnesses and those of the active criminals. If everybody is equally guilty, then nobody really is guilty, and one can easily segue from generalized questioning into overall self-satisfaction. Such a form of fictional political revisionism leaves the "Greatest Generation" of Americans who took on Nazi Germany stranded in the shadow of moral ambiguity. However, the positive reception of this novel-except for the criticism offered by the director Claude Lanzmann and the historian Annette Wieviorka - showed how the underlying thesis of the book did resonate with a certain present state of the postmemory of the genocide.

In 1986, in a famous chapter of The Drowned and the Saved entitled "The Gray Zone," Primo Levi developed the eponymous concept, which is essential to understanding the context of the genocide and of the camps. Yet 
he also warned against the risks of misunderstanding the expression: the "gray zone" is all the rage now, but it has been affected by the same process of conceptual trivialization as Hannah Arendt's famous phrase "the banality of evil." Haenel's book may be the most striking expression of a commonsense mistake about the notion of the "gray zone." In Primo Levi's mind this expression was a call to exercise one's judgment about extreme situations with a mixture of moral restraint, prudence, and sensitivity to their complexity. A certain tendency within the present postmemory is to do the exact opposite: in order to appease the anguished questioning about responsibility, the tendency is to confuse everything and stop the effort of moral reflection at the lowest level.

From "What did the victims go through and what do we owe them?" to "How do we position ourselves today in relation to moral choices made at the time?" the ethical turn of French memory politics that can be identified over the past fifteen years has been accompanied by an abundant postmemory literary creation from the third generation, in the sense of a national third generation, not just the third generation in a family or a community. Since in France, as in most of the Western world, the genocide of the Jews is the yardstick by which evil is measured, this ethical turn involves moral questions, as other genocides do. The concept of Righteous among the Nations, invented in Israel and based on Jewish tradition, is already being used widely in the context of other genocides: what political and memory uses will it serve in such a comparative perspective? Indeed, this ethical turn has made it possible to avoid, to a certain point, memories competing with one another and the French Republic being threatened by community claims regarding memory.

\section{Notes}

1. Marianne Hirsch, The Generation of Postmemory: Writing and Visual Culture after the Holocaust (New York: Columbia University Press, 2012).

2. Ivan Jablonka, Histoire des grands-parents que je n'ai jamais eus (Paris: Seuil, 2012).

3. Virginie Linhart, La vie après (Paris: Seuil, 2012).

4. Linhart, La vie après, 24.

5. Linhart, La vie après, 20.

6. Michel Kichka, Deuxième génération (Paris: Dargaud, 2012). 
7. Kichka, Deuxième génération, 17.

8. Kichka, Deuxième génération, 5-6.

9. Kichka, Deuxième génération, 10.

10. Journée nationale à la mémoire des victimes des crimes racistes et antisémites de l'Etat français et d'hommage aux "Justes" de France (law of July 10, 2000), as described on the French Defense Ministry website, www.defense.gouv.fr/content/ download/100759/978285/file/MC18.pdf.

11. Alexandre Jardin, Des gens très bien (Paris: Grasset, 2010).

12. Pierre Bayard, Aurais-je été résistant ou bourreau? (Paris: Minuit, 2012).

13. Primo Levi, The Drowned and the Saved (New York: Summit Books, 1988).

14. Yannick Haenel, Jan Karski (Paris: Gallimard, 2009); translated as The Messenger (New York: Counterpoint, 2012). 